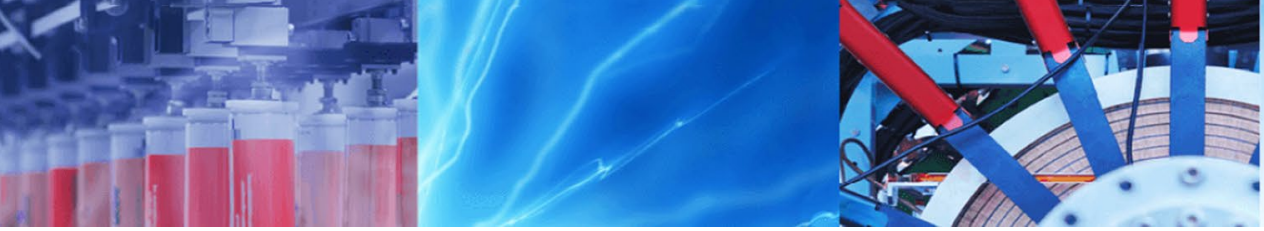

Research Article

\title{
Stable carbon in soils under rubber tree (Hevea brasiliensis) agroforestry systems in the south of Bahia, Brazil
}

\author{
Gerbeli Mattos Salgado ${ }^{1}$ Emanuela Forestieri Gama-Rodrigues ${ }^{2}$ (D) - Laís Carvalho Vicente ${ }^{2}$. \\ Antonio Carlos Gama-Rodrigues ${ }^{2}$. Seldon Aleixo ${ }^{2}$. José Raimundo Bonadie Marques ${ }^{3}$
}

() Springer Nature Switzerland AG 2019

\begin{abstract}
The early natural forest conversion to pasture, rubber tree plantations or agroforestry systems (AFSs) will not negatively affect soil organic carbon (SOC) accumulation due to the lack of soil tillage and the continuous contribution of vegetal residues to the soil, over the years, which would favor $C$ occlusion in soil aggregates. The objectives of this study were: to evaluate the potential of AFSs with rubber trees to accumulate $S O C$ up to $100 \mathrm{~cm}$; to evaluate the $\delta^{13} \mathrm{C}$ variations over the soil profile after forest to pasture and rubber tree plantation (RTP) conversion; and to verify the $C$ physical protection in aggregates as a mechanism of $C$ stability in these soils. $S O C$ was quantified up to $100 \mathrm{~cm}$ in whole soil and in three fraction-size classes (macroaggregates, microaggregates and silt + clay class). The occluded $\mathrm{C}$ was quantified in macroand microaggregates by using an ultrasonic method. The relative contributions of $C_{3}$ and $C_{4}$ plants-derived $C$ were quantified. The RTP system presented the highest SOC values, up to $100 \mathrm{~cm}$ depth, contributing with $20 \mathrm{MgCha}^{-1}$ from belowground input, during 35 -year old of system implantation. However, about $90 \%$ of SOC was not physically protected in the soil aggregates. The forest to rubber + cacao agroforestry system (AFS) conversion reduced SOC stock up to $100 \mathrm{~cm}$ approximately $72 \mathrm{Mg} \mathrm{ha}^{-1}$, and the reduction in SOC stock after forest to rubber tree + açaí AFS was around $34 \mathrm{Mg} \mathrm{ha}^{-1}$. Rubber tree + cacao and rubber tree + açaí AFSs had significant contributions of occluded C in soil aggregates.
\end{abstract}

Keywords Soil aggregates $\cdot{ }^{13} \mathrm{C} /{ }^{12} \mathrm{C} \cdot \mathrm{Cacao}$, açaí $\cdot$ Atlantic forest $\cdot$ Physical protection

\section{Introduction}

Agroforestry systems (AFSs) are sustainable land uses that combine, simultaneously or sequentially, agricultural crop production with tree or fruit tree plantations and/or animals using the same land unit and applying techniques which are compatible with the cultural practices of the local population [33]. AFSs are recognized as soil exploration models that are more ecologically similar to natural forests and function as environmental service providers, such as high potential for sequester soil organic carbon
(SOC) $[32,34]$. The estimate of AFSs potential to sequester carbon $(C)$ in a global scale is $1.1-2.2 \mathrm{Pg}$ of $\mathrm{C}$ over 50 years, above and belowground [11]. The $\mathrm{C}$ credit sale due to the rubber tree $C$ sequestration, in pure plantations and also in agroforestry systems, can be a source of income for the smallholder farmers and encourage the expansion of forest and agroforestry production in Brazil.

A rubber tree (Hevea brasiliensis Muell. Arg), which is one of the major tree crops of economic interest in tropical regions of the world [21], is an example of a tree species that has been used in AFSs with diverse crops, such as

Emanuela Forestieri Gama-Rodrigues, emanuela@uenf.br; Gerbeli Mattos Salgado, gerbeli_salgado@hotmail.com; Laís Carvalho Vicente, laiscvicente@gmail.com; Antonio Carlos Gama-Rodrigues, tonygama@uenf.br; Seldon Aleixo, seldon_aleixo@mail.com; José Raimundo Bonadie Marques, bonadiemarques@yahoo.com.br| ${ }^{1}$ Universidade Estadual da Região Tocantina do Maranhão/UEMASUL, Imperatriz, MA CEP 65901-480, Brazil. ²UENF/CCTA/Soil Laboratory, Universidade Estadual do Norte Fluminense Darcy Ribeiro UENF, Av. Alberto Lamego 2000, Campos dos Goytacazes, RJ CEP 28013-602, Brazil. ${ }^{3}$ CEPEC/CEPLAC, Km 22, Rodovia Ilhéus, Itabuna, BA CEP 45600-970, Brazil.

SN Applied Sciences (2019) 1:790 | https://doi.org/10.1007/s42452-019-0815-7

Received: 6 February 2019 / Accepted: 20 June 2019 / Published online: 26 June 2019 
açaí (Euterpe oleracea), cacao (Theobroma cacao), acerola (Malpighia glabra), guaraná (Paullinia cupana Kunth), red pepper (Piper nigrum), urucum (Bixa orellana), maize (Zea mays), bean (Phaseolus vulgaris), among others [41]. In Brazil, there are around 170 thousand ha of planted area with rubber trees, and this is expanding for several reasons: (1) Latex and wood are being produced for multiple purposes; (2) rubber tree is considered a viable production alternative to aid in the reduction in socioeconomic and environmental problems; (3) planting rubber trees supplies work for a large labor force; (4) rubber tree is highly adapted to stabilize and recover degraded areas; and (5) rubber tree contributes to climatic effects mitigation due to $C$ sequestration, both in plant biomass and in soil, with an economic useful life of 20-40 years and the extension of this productive period being mainly determined by the intensity of latex extraction [27]. In this sense, rubber tree AFS can be considered an intelligent agricultural system for the climate (climate-smart agriculture).

There are three relevant aspects to be considered in SOC stock studies. The first is the soil's deepest horizons, which are responsible for more than half of the accumulated $C$ in the profile. This $C$ is derived from roots and remains stable in the soil due to its more lignified constitution, which makes this material decompose more slowly $[19,39]$. The second aspect is the origin of $C$ in soils where there were forest to pasture or pasture to forest plantations or agroforestry conversions. The ${ }^{13} \mathrm{C}$ isotopic tracking technique behaves as a digital identification of the $C$ source being deposited in the soil. When replacing a secondary forest $\left(C_{3}\right)$ with a $C-C_{4}$ source crop or pasture, it is possible to analyze how much the new source of $C$ is contributing to the current stock in the soil $[2,4]$. Plants with a $C_{3}$ cycle, a characteristic of forests, have a $\delta^{13} \mathrm{C}$ value between -35 and $-20 \%$, with an average value close to $-27 \%$ o. Plants with a $\mathrm{C}_{4}$ cycle, a characteristic of grasses and some agricultural systems, have a $\delta^{13} \mathrm{C}$ value between -18 and $-8 \%$, with an average value close to $-13 \%$. These values are much more negative than those found in the $\mathrm{CO}_{2}$ in the air, around $-7.4 \%$, and are directly connected with their $C$ source $[4,15]$. Finally, $C$ stabilization within the aggregates is an important mechanism to reduce the bioavailability and accessibility of organic matter for soil microorganisms and enhance the potential of $C$ sequestration in soils [42]. The hypothesis of the present study was that in heavily weathered soils, early natural forest conversion to pasture or rubber tree plantations or rubber tree AFSs (rubber tree + cacao or rubber tree + açaí) will not negatively affect $\mathrm{SOC}$ accumulation due to the lack of soil tillage and the continuous contribution of vegetal residues to the soil over the years which would favor $C$ occlusion in soil aggregates. Thus, the objectives were: (1) to evaluate the potential of rubber tree AFSs and pure RTP to accumulate SOC up to $100 \mathrm{~cm}$ in comparison with an adjacent secondary forest and pasture; (2) to evaluate the variation in $\delta^{13} \mathrm{C}$ along the soil profile after the conversion of forest to pasture, as well as in RTP with grass predominance in their understory composition; and (3) to verify the physical protection of $C$ in the aggregates as a mechanism of $C$ stability in these soils.

\section{Materials and methods}

\subsection{Study sites}

This study was performed in the areas of the Experimental Station Djalma Bahia (EDJAB) in the municipality of Una (15 $\left.17^{\circ} 20.44^{\prime \prime} \mathrm{S}, 39^{\circ} 3^{\prime} 39.44^{\prime \prime} \mathrm{W}\right)$ in the south region of Bahia, Brazil, in a flat land with $63 \mathrm{~m}$ of altitude. According to the Köppen classification system, the climate is classified as Af and is characterized by an annual precipitation of $2000 \mathrm{~mm}$ and an average annual temperature of $26^{\circ}$ C (Climatological Station of CEPLAC, unpublished data). The soils were classified as Dystrophic Grayish Argisols (Ultisols) [8]. The previous vegetation was a secondary forest, which was felled for agroforestry systems, rubber tree plantations and pasture implantations, and the area of each land use was 1 ha. These AFSs and the rubber tree plantation, composed of different ages, were chosen because they were the most homogeneous and welldeveloped plantations:

(1) 35-year-old rubber tree (Hevea brasiliensis) plantation (RTP): spacing was $7 \mathrm{~m} \times 3 \mathrm{~m}$ (476 plants ha $\left.{ }^{-1}\right)$, with grasses (Paspalum Notatum Fluegge and Cynodon dactylon) as soil cover. This system has been without inorganic fertilization since 1982.

(2) Secondary forest-SF, classified as Dense Ombrophylle Lowland Forest, whose structural and physiognomic characteristics are similar to the Amazon Rain Forest. Approximately $30 \%$ of the trees with approximately $30 \mathrm{~cm}$ of diameter had been removed. Currently, these forest fragments are maintained preserved.

(3) 8-year-old unfertilized pasture (PAS) composed of Brachiaria decumbens. Before the pasture was installed, the area had remained fallow for approximately 30 years. We chose this pasture, even though it was much younger than the other land-use systems, because it was the only one available at the experimental station.

(4) 30-year-old rubber tree (Hevea brasiliensis) and açaí palm (Euterpe oleracea Mart) AFS - RT + A: rubber tree and açaí spacing was $7 \mathrm{~m} \times 3 \mathrm{~m}$ (476 plants ha ${ }^{-1}$ ) in a quincunx planting pattern. Açaí was planted to 
produce palm hearts. Açaí fertilization was applied to the crown of each tree 67,13 and $67 \mathrm{~kg} / \mathrm{ha}$ of urea, potassium chloride and triple superphosphate, respectively. This system has been without inorganic fertilization since 1987 [1].

(5) 35-year-old rubber tree (Hevea brasiliensis) and cacao (Theobroma cacao) AFS - RT + C: cacao spacing was in double rows of $2 \times 2 \mathrm{~m}$, lines $L 1$ and $L 2$ were planted at a distance of $2.5 \mathrm{~m}$ from the hevea hedgerows and rubber tree spacing was $7 \times 3 \mathrm{~m}$. Cacao fertilization consisted of 1107,778 and $932 \mathrm{~kg} / \mathrm{ha}$ of limestone; $222,821,292$ and $525 \mathrm{~kg} / \mathrm{ha}$ of $\mathrm{N}: \mathrm{P}_{2} \mathrm{O}_{5}: \mathrm{K}_{2} \mathrm{O}$ as $11: 30: 17 ; 244 \mathrm{~kg} / \mathrm{ha}$ of $\mathrm{N}: \mathrm{P}_{2} \mathrm{O}_{5}: \mathrm{K}_{2} \mathrm{O}$ as $13: 35: 10$ and ammonium sulfate and micronutrients (181 and $56 \mathrm{~kg} / \mathrm{ha}$, respectively). This system has been without inorganic fertilization since 1987 [1].

Rubber tree fertilization in all land uses consisted of 22, 115,78 and $100 \mathrm{~kg} / \mathrm{ha}$ of triple superphosphate; 54,19 and $38 \mathrm{~kg} / \mathrm{ha}$ of potassium chloride; 91 and $70 \mathrm{~kg} / \mathrm{ha}$ of urea; and $97 \mathrm{~kg} / \mathrm{ha}$ of ammonium sulfate [1].

\subsection{Soil sampling and analysis}

Four fixed plots $(30 \times 30 \mathrm{~m})$ were defined in the center of each land-use system (i.e., four pseudoreplicates), within the same original area with the same previous land-use history and also the same topographic position, separated by at least $100 \mathrm{~m}$. Trenches $(1 \times 1 \times 1.5 \mathrm{~m})$ were dug randomly between the plant rows using a zigzag pattern in each plot. The soil was sampled at six depths $(0-10,10-20,20-40,40-60,60-80$ and $80-100 \mathrm{~cm})$. These depth classes were chosen in accordance with the protocol used for a multi-country study on soil $C$ sequestration in AFSs [30,46]. Soil samples from each depth were air-dried and passed through a 2-mm sieve. Soil particle size was determined using the pipette method, and the volumetric ring method was used to determine soil bulk density (Embrapa [14] (Table 1 ). The SOC and total N were determined by dry combustion in an automated elemental analyzer (CHNS/O analyzer). The following measurements were performed using the methods described in Embrapa [14]: $\mathrm{pH}$ was measured with a glass electrode in 1:2.5 water stirred suspension. Exchangeable $\mathrm{Ca}^{2+}, \mathrm{Mg}^{2+}$ and $\mathrm{Al}^{3+}$ were extracted with $1 \mathrm{~mol} \mathrm{~L}^{-1} \mathrm{KCl}$. $\mathrm{P}$ and $\mathrm{K}$ were extracted with Mehlich-1. $\mathrm{Ca}^{2+}, \mathrm{Mg}^{2+}$ and $\mathrm{Al}^{3+}$ in extract were determined by atomic absorption spectrophotometry. $K$ concentrations were determined by flame emission spectrophotometry. $\mathrm{P}$ was determined by colorimetry with ascorbic acid by spectrophotometry (Table 2).

The soil bulk density at each depth was used to calculate the total amount of SOC stored to a depth of $1 \mathrm{~m}$ and was expressed in $\mathrm{Mg} \mathrm{ha}^{-1}$. The SOC stock was later
Table 1 Particle size fractions (sand. silt and clay) and bulk density at different depths in rubber tree agroforestry systems, secondary forest and pasture in Bahia, Brazil

\begin{tabular}{lrrrrr}
\hline & \multicolumn{6}{l}{ Land-use systems } \\
\cline { 2 - 6 } & \multicolumn{1}{c}{ SF } & \multicolumn{1}{c}{ PAS } & \multicolumn{1}{c}{ RT } & RT + A & RT + C \\
\hline $\mathrm{pH}\left(\mathrm{H}_{2} \mathrm{O}\right)$ & 4.52 & 4.60 & 3.50 & 3.70 & 3.70 \\
$\mathrm{P}\left(\mathrm{mg} \mathrm{kg}^{-1}\right)$ & 0.80 & 1.60 & 11.20 & 4.40 & 5.80 \\
$\mathrm{~K}\left(\mathrm{mg} \mathrm{kg}^{-1}\right)$ & 33.00 & 40.00 & 32.00 & 26.00 & 29.00 \\
$\mathrm{Ca}\left(\mathrm{cmolc} \mathrm{dm}^{-3}\right)$ & 0.16 & 1.15 & 0.42 & 0.14 & 0.50 \\
$\mathrm{Mg}\left(\mathrm{cmolc} \mathrm{dm}^{-3}\right)$ & 0.48 & 0.53 & 0.22 & 0.14 & 0.62 \\
$\mathrm{Al}\left(\mathrm{cmolc} \mathrm{dm}^{-3}\right)$ & 1.40 & 0.50 & 2.20 & 1.20 & 1.80 \\
$\mathrm{H}+\mathrm{Al}\left(\mathrm{cmolc} \mathrm{dm}^{-3}\right)$ & 11.20 & 9.90 & 14.90 & 9.70 & 10.90 \\
$\mathrm{SB}\left(\mathrm{cmolc} \mathrm{dm}^{-3}\right)$ & 1.42 & 2.30 & 1.72 & 0.95 & 1.69 \\
\hline
\end{tabular}

$B D$ bulk density, SF secondary forest, $P A S$ pasture, $R T$ rubber tree plantation, $R T+A$ rubber tree and açai agroforestry system, $R T+C$ rubber tree and cacao agroforestry system

corrected by the clay content of the soil under the natural forest and used as a reference, as suggested by Moraes et al. [31], as the SOC level variations were closely related to soil texture. Therefore, this correction is to remove the effect of clay content and to show the possible variations in soil $C$ stock resulting from the differences between landuse systems.

The SOC content was corrected for each depth using the following equation:

$\mathrm{C}_{(\text {corrected })}=\mathrm{C}_{\left(\text {measured g } 100 \mathrm{~g}^{-1}\right)} * \frac{\text { clay content }_{(\text {reference) }}}{\text { clay content }_{\text {(treatment })}}$

Since SOC levels of a given soil layer also depend on the soil compaction, we corrected the SOC levels for compaction using natural forest soils as Ref. [13].

The following equation was used to calculate the thickness and the soil layer compaction that should be considered:

$E_{\mathrm{ad} / \mathrm{sub}}=\frac{\left[\frac{\left(M_{\text {reference }}-M_{\text {treatmeant }}\right)}{D s}\right]}{100}$

where $E_{\mathrm{ad} / \mathrm{sub}}=$ depth to be added or subtracted in the stock calculation $(\mathrm{cm}) ; M_{\text {ref }}=$ soil mass at the reference soil depth $\left(\mathrm{Mg} \mathrm{ha}^{-1}\right) ; M_{\text {trat }}=$ soil mass at the assessed soil depth (Mg ha $\left.{ }^{-} 1\right)$; and $D s=$ soil bulk density $\left(\mathrm{g} / \mathrm{cm}^{3}\right)$.

Natural ${ }^{13} \mathrm{C}$ abundance was determined to obtain the $\mathrm{C}$ isotope ratio $\left({ }^{13} \mathrm{C} /{ }^{12} \mathrm{C}\right)$ and distinguish between residues from $\mathrm{C}_{3}$ (e.g., forestry and agroforestry systems, indicating the presence of trees) and $\mathrm{C}_{4}$ plants (in this study a pasture with a predominance of Brachiaria). Thus, the natural ${ }^{13} \mathrm{C}$ abundance method was only used in secondary forest $\left(C_{3}\right.$ plants), pasture $\left(C_{4}\right.$ plants $)$ and RTP $\left(C_{3}\right.$ plants $)$. Pasture 
Table 2 Chemical attributes $(0-10 \mathrm{~cm})$ of soils under rubber tree agroforestry systems, secondary forest and pasture in Bahia, Brazil

\begin{tabular}{|c|c|c|c|c|c|c|}
\hline Depth (cm) & $\begin{array}{l}\text { Particle size fraction (\%) and } \\
\text { bulk density }\left(\mathrm{g} \mathrm{cm}^{-3}\right)\end{array}$ & SF & PAS & RT & $\mathrm{RT}+\mathrm{A}$ & $\mathrm{RT}+\mathrm{C}$ \\
\hline \multirow[t]{4}{*}{$0-10$} & Sand & 45.69 & 53.70 & 42.41 & 43.87 & 35.87 \\
\hline & Silt & 14.20 & 3.66 & 9.21 & 7.17 & 6.82 \\
\hline & Clay & 40.11 & 42.64 & 48.38 & 48.95 & 57.30 \\
\hline & $\mathrm{BD}$ & 1.03 & 1.54 & 1.22 & 1.15 & 1.16 \\
\hline \multirow[t]{4}{*}{$10-20$} & Sand & 42.83 & 52.67 & 37.89 & 42.31 & 30.95 \\
\hline & Silt & 19.94 & 9.10 & 7.25 & 7.40 & 7.56 \\
\hline & Clay & 42.23 & 38.23 & 54.87 & 50.29 & 61.50 \\
\hline & $\mathrm{BD}$ & 1.20 & 1.43 & 1.34 & 1.28 & 1.20 \\
\hline \multirow[t]{4}{*}{$20-40$} & Sand & 38.52 & 46.90 & 31.91 & 36.87 & 26.76 \\
\hline & Silt & 7.97 & 7.38 & 7.18 & 6.88 & 6.53 \\
\hline & Clay & 53.50 & 45.73 & 60.92 & 56.25 & 66.72 \\
\hline & $\mathrm{BD}$ & 1.34 & 1.50 & 1.38 & 1.36 & 1.26 \\
\hline \multirow[t]{4}{*}{$40-60$} & Sand & 32.60 & 43.13 & 27.57 & 32.89 & 23.95 \\
\hline & Silt & 5.98 & 5.03 & 3.89 & 7.84 & 5.06 \\
\hline & Clay & 61.42 & 51.84 & 68.54 & 59.27 & 70.99 \\
\hline & $\mathrm{BD}$ & 1.36 & 1.46 & 1.36 & 1.34 & 1.26 \\
\hline \multirow[t]{4}{*}{$60-80$} & Sand & 35.04 & 38.79 & 25.93 & 29.35 & 21.80 \\
\hline & Silt & 1.05 & 5.04 & 8.85 & 4.71 & 6.81 \\
\hline & Clay & 61.42 & 56.16 & 65.22 & 65.94 & 71.38 \\
\hline & $\mathrm{BD}$ & 1.22 & 1.38 & 1.28 & 1.30 & 1.15 \\
\hline \multirow[t]{4}{*}{ 80-100 } & Sand & 31.60 & 40.89 & 25.63 & 29.35 & 20.59 \\
\hline & Silt & 2.17 & 5.35 & 5.11 & 4.71 & 3.76 \\
\hline & Clay & 66.23 & 53.76 & 69.26 & 70.25 & 75.64 \\
\hline & $B D$ & 1.24 & 1.37 & 1.28 & 1.32 & 1.18 \\
\hline
\end{tabular}

$S F$ secondary forest, $P A S$ pasture, $R T$ rubber tree plantation, $R T+A$ rubber tree and açai agroforestry system, $R T+C$ rubber tree and cacao agroforestry system system was implemented in an area that was previously cultivated with $\mathrm{C}_{3}$ vegetation (secondary forest), and RTP had in its understory a grass predominance. The ${ }^{13} \mathrm{C} /{ }^{12} \mathrm{C}$ ratio $\left(\delta^{13} \mathrm{C}\right)$ was determined using a continuous-flow isotope ratio mass spectrometer (Finnigan Delta Plus) coupled with an automated $\mathrm{C}$ and $\mathrm{N}$ analyzer (Carlo Erba EA 1108) at USP/Nuclear Energy Center of Agriculture (Centro de Energia Nuclear na Agricultura). The results were expressed in \%o relative to the Pee Dee Belemnite (PDB) international standard and calculated using the following equation: $\delta^{13} \mathrm{C}=\frac{\mathrm{R}_{\text {sample }}-R_{\text {reference }}}{R_{\text {reference }}}$ where $R$ sample $={ }^{13} \mathrm{C} /{ }^{12} \mathrm{C}$ ratio of the sample and $\mathrm{R}$ reference $={ }^{13} \mathrm{C} /{ }^{12} \mathrm{C}$ ratio of the sample.

The next equation [47] was used to determine the proportion of $C_{4}$ plant-derived (pasture) $C$ at a depth of $0-20 \mathrm{~cm}$ (where differences in the $\delta^{13} \mathrm{C}$ were found):

$\% \mathrm{C}-\mathrm{C}_{4}=\frac{\delta-\delta_{o}}{\delta_{p}-\delta_{o}} * 100$

where $\delta=$ natural ${ }^{13} \mathrm{C}$ abundance in the samples; $\delta_{0}=$ natural ${ }^{13} \mathrm{C}$ abundance in the soil samples without $C_{4}$ plant residues (a natural forest was used as a reference); and $\delta_{p}=$ natural ${ }^{13} \mathrm{C}$ abundance of the pasture plant material $(-12.65 \%)$.

The following equation was used to obtain the $\%$ of $\mathrm{C}_{3}$ carbon:

$\% C-C_{3}=100-\% C-C_{4}$

\subsection{Physical fractionation}

Aggregate fractionation was carried out according to the procedure of Elliot [12], adapted as described by GamaRodrigues et al. [17]. First, soil samples obtained from the field were air-dried and passed through a 2-mm sieve. The procedure consisted of submerging $100 \mathrm{~g}$ of the soil sample $(<2000 \mu \mathrm{m})$ in a $500-\mathrm{mL}$ beaker of deionized water for about $5 \mathrm{~min}$ before placing it on top of a $250-\mu \mathrm{m}$ sieve. The sieving was done manually, moving the sieve $\sim 3 \mathrm{~cm}$ up and down during a period of $2 \mathrm{~min}$. The samples were physically fractionated by wet-sieving through a series of two sieve sizes ( 250 and $53 \mu \mathrm{m}$ ), and three aggregate size fractions were obtained: macroaggregate (2000-250 $\mu \mathrm{m})$, microaggregate $(250-53 \mu \mathrm{m})$ and silt-and-clay size fraction 
$(<53 \mu \mathrm{m})$. All fraction classes were air-dried at $60^{\circ} \mathrm{C}$, and the percent weight of each fraction was calculated.

\subsection{Sonication}

The purpose of sonification technique was to promote the complete aggregates disruption. The sonication procedure consisted of weighing $5 \mathrm{~g}$ of macroaggregate or $3 \mathrm{~g}$ of microaggregate in a $500-\mathrm{mL}$ beaker to which $150 \mathrm{ml}$ of deionizer water was added. The suspension was sonicated at $600 \mathrm{~J} \mathrm{ml}^{-1}$ (chosen after a prior test) by using an amplitude of $40 \%$ and in 20-minute combinations with a Sonic Dismembrator. The pulse method (60 s on and $30 \mathrm{~s}$ off) and ice were used to keep the temperature below $35^{\circ} \mathrm{C}$ to avoid cavitation reduction $[38,40]$. The depth immersion of the sonificator probe was kept constant at $10 \mathrm{~mm}$. After sonication, the suspension was passed through the same-sized sieve used to obtain the size fraction (e.g., 250$\mu \mathrm{m}$ sieve for the macroaggregate and $53-\mu \mathrm{m}$ sieve for the microaggregate). The fraction that remained on the sieve after sonication was not analyzed (fraction composed mainly of sand), and the fraction that passed through the sieve was termed aggregate-organic-matter fraction $\left(\mathrm{AOM}_{\mathrm{f}}\right)$.

The occluded C $(O C)$ in the AOMf was determined by dry combustion using an automated Perkin-Elmer Series II 2400 CHNS/O analyzer.

The OC stock in macro- and microaggregates stock $\left(\mathrm{Mg} \mathrm{ha}^{-1}\right)$ was calculated as follows:

Step 1: $C$ content in AOMf:

$\mathrm{C} \mathrm{AOMf}=\left(\mathrm{C} * W_{\mathrm{AOMf}} * \mathrm{WF}\right) /(100 * \mathrm{iWf})$

where $\mathrm{C}=\mathrm{C}$ concentration measured in AOMf $(\mathrm{g}$ $\left.100 \mathrm{~g}^{-1}\right), W_{\mathrm{AOMf}}=$ weight of AOMf $(\mathrm{g}), \mathrm{WF}=$ weight of the size fraction, obtained in physical fractionation $(\mathrm{g})$, $\mathrm{iWf}=$ initial weight of size fraction $(5 \mathrm{~g}$ for macro- and $3 \mathrm{~g}$ for microaggregate)

Step 2: OC stock $\left(\mathrm{Mg} \mathrm{ha}^{-1}\right)$

$\mathrm{OC}$ stock $=\left(\mathrm{C}\right.$ content in $\left.\mathrm{AOMf}{ }^{*} \mathrm{WF}^{*} \mathrm{BD} * \mathrm{SDI}\right) * \mathrm{Ci}$

where $C$ content in AOMf is obtained in step 1 , $\mathrm{WF}=$ weight of the size fraction, obtained in physical fractionation $(\mathrm{g}), \mathrm{BD}=$ soil bulk density in $\mathrm{kg} \mathrm{dm}^{-3}$, $\mathrm{SDI}=$ soil depth interval $(\mathrm{cm}), \mathrm{Ci}=0,01$ (convert unit to $\mathrm{Mg} \mathrm{ha}^{-1}$ )

\section{Statistical analysis}

Each site was considered a fixed-effect treatment due to the multiple sources of variation, such as land-use systems (agroforestry systems, pasture and rubber tree plantation), different management practices and the ages of the plantations [25]. This assumption was previously explained for cacao agroforestry and forest systems [10, 16, 30, 37, 46]. To evaluate the normal distribution of the variables analyzed, data were tested for normality by Kolmogorov-Smirnov and Lilliefors, and homoscedasticity and normal distribution residues. The data were transformed to $\sqrt{ } X$. In sequence, the data were analyzed by analysis of variance (ANOVA) as a completely randomized design with four replicates. As each plot was located at least $100 \mathrm{~m}$ from each other, we assumed that they were independent from each one, which validated our use of analysis of variance (ANOVA) [24]. The data were analyzed using Assistat software (exception $\delta^{13} \mathrm{C}$ ). SigmaPlot 11.0 (Systat Software inc., [43] was used to build the graphics.

\section{Results}

\subsection{Soil fertility level and soil organic carbon (SOC) stocks}

All of the sites studied exhibited clayey to very clayey soils, high acidity, very low extractable $\mathrm{P}$ concentrations, low-to-medium base sum and Al concentration and high potential acidity (Tables 1, 2). At $100 \mathrm{~cm}$ depth, the RTP stored around $9 \%$ more SOC and AFSs between 21 and $44 \%$ less than the secondary forest (Fig. 1). In general, SOC stock varied among systems at all depths; however, while AFSs contributed similarly along the soil profile, the pasture accumulated $48 \%$ and $28 \%$ of the total SOC stock, respectively, in the first $20 \mathrm{~cm}$ and below $40 \mathrm{~cm}$. On the

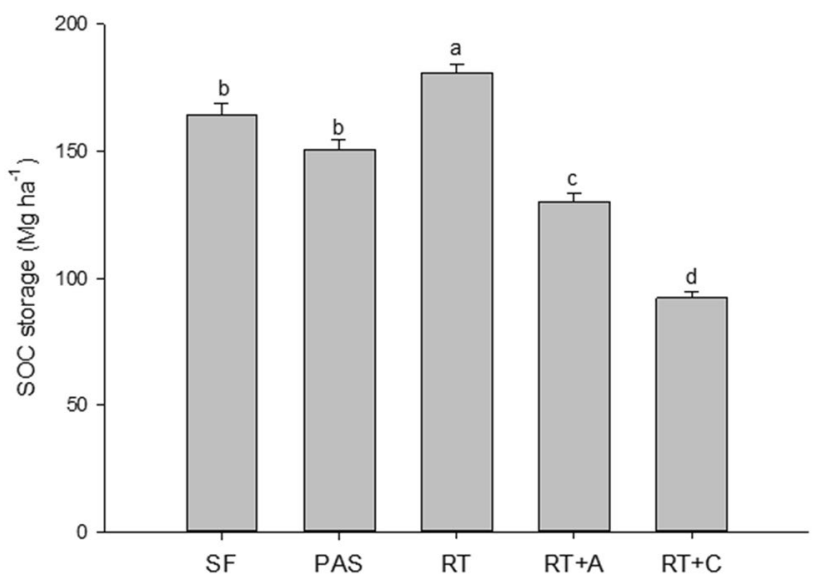

Fig. 1 Soil organic carbon (SOC; $M g$ ha $^{-1}$ ) stocks, upper to $1 \mathrm{~m}$, in soils under rubber tree agroforestry systems, secondary forest and pasture in Bahia, Brazil. SF: secondary forest; PAS: pasture; RT: rubber tree plantation; $\mathrm{RT}+\mathrm{A}$ : rubber tree and açai agroforestry system; RT $+C$ : rubber tree and cacao agroforestry system. Values followed by the same letter(s) within land-use systems are not significantly different according to Scott-Knott test $(P=0.05)$; vertical bars represent \pm standard error 
other hand, the rubber tree plantation in the first $20 \mathrm{~cm}$ contributed $29 \%$ to the SOC stock. Below $40 \mathrm{~cm}$ depth, the contribution was approximately $47 \%$ of the total SOC up to $100 \mathrm{~cm}$ (Table 3 ).

\section{Variation in $\delta{ }^{13} \mathrm{C}$ with depth in secondary forest, pasture and rubber tree plantation}

The highest $\delta^{13} \mathrm{C}$ value variation occurred in the first $10 \mathrm{~cm}$, where the secondary forest presented the most negative values, ranging around $-28 \%$, followed by

Table 3 Occluded $\mathrm{C}$ in macroaggregates $\left(\mathrm{OC}_{\mathrm{Ma}}\right)$ and in microaggregate $\left(\mathrm{OC}_{\mathrm{Mi}}\right)$ at different depths in rubber tree agroforestry systems, secondary forest and pasture in Bahia, Brazil

\begin{tabular}{|c|c|c|c|}
\hline Land-use systems & Depth $(\mathrm{cm})$ & $\mathrm{OC}_{\mathrm{Ma}}\left(\mathrm{Mg} \mathrm{ha}^{-1}\right)$ & $O C_{M i}$ \\
\hline SF & \multirow[t]{5}{*}{$0-10$} & $7.68^{a}$ & $0.93^{b}$ \\
\hline PAS & & $10.15^{\mathrm{a}}$ & $1.44^{b}$ \\
\hline RT & & $5.23^{b}$ & $2.50^{\mathrm{a}}$ \\
\hline $\mathrm{RT}+\mathrm{A}$ & & $9.42^{\mathrm{a}}$ & $2.47^{a}$ \\
\hline $\mathrm{RT}+\mathrm{C}$ & & $8.41^{\mathrm{a}}$ & $1.45^{\mathrm{b}}$ \\
\hline SF & \multirow[t]{5}{*}{$10-20$} & $5.60^{\mathrm{a}}$ & $2.43^{\mathrm{a}}$ \\
\hline PAS & & $5.35^{\mathrm{a}}$ & $1.27^{b}$ \\
\hline RT & & $3.57^{\mathrm{a}}$ & $2.44^{\mathrm{a}}$ \\
\hline $\mathrm{RT}+\mathrm{A}$ & & $3.71^{\mathrm{a}}$ & $2.88^{\mathrm{a}}$ \\
\hline $\mathrm{RT}+\mathrm{C}$ & & $5.15^{\mathrm{a}}$ & $1.55^{b}$ \\
\hline SF & \multirow[t]{5}{*}{$20-40$} & $6.33^{a}$ & $1.77^{b}$ \\
\hline PAS & & $3.11^{b}$ & $3.72^{\mathrm{a}}$ \\
\hline RT & & $5.52^{\mathrm{a}}$ & $4.37^{\mathrm{a}}$ \\
\hline $\mathrm{RT}+\mathrm{A}$ & & $7.32^{\mathrm{a}}$ & $3.52^{\mathrm{a}}$ \\
\hline $\mathrm{RT}+\mathrm{C}$ & & $6.69^{a}$ & $4.78^{a}$ \\
\hline SF & \multirow[t]{5}{*}{$40-60$} & $4.70^{\mathrm{a}}$ & $3.23^{\mathrm{a}}$ \\
\hline PAS & & $1.85^{b}$ & $3.85^{\mathrm{a}}$ \\
\hline RT & & $4.00^{\mathrm{a}}$ & $4.53^{\mathrm{a}}$ \\
\hline $\mathrm{RT}+\mathrm{A}$ & & $4.93^{a}$ & $4.30^{\mathrm{a}}$ \\
\hline $\mathrm{RT}+\mathrm{C}$ & & $4.39^{a}$ & $4.26^{a}$ \\
\hline SF & \multirow[t]{5}{*}{$60-80$} & $1.93^{\mathrm{a}}$ & $11.99^{a}$ \\
\hline PAS & & $1.09^{a}$ & $12.80^{\circ}$ \\
\hline RT & & $1.88^{\mathrm{a}}$ & $3.12^{b}$ \\
\hline $\mathrm{RT}+\mathrm{A}$ & & $3.48^{\mathrm{a}}$ & $3.83^{b}$ \\
\hline $\mathrm{RT}+\mathrm{C}$ & & $2.61^{a}$ & $3.83^{b}$ \\
\hline SF & \multirow[t]{5}{*}{ 80-100 } & $1.40^{b}$ & $9.56^{\mathrm{a}}$ \\
\hline PAS & & $0.98^{b}$ & $5.87^{b}$ \\
\hline $\mathrm{RT}$ & & $2.53^{\mathrm{a}}$ & $3.71^{b}$ \\
\hline $\mathrm{RT}+\mathrm{A}$ & & $3.27^{\mathrm{a}}$ & $3.45^{b}$ \\
\hline $\mathrm{RT}+\mathrm{C}$ & & $2.84^{\mathrm{a}}$ & $3.90^{b}$ \\
\hline
\end{tabular}

SF secondary forest, PAS pasture, $R T$ rubber tree plantation, $R T+A$ rubber tree and açai agroforestry system, $R T+C$ rubber tree and cacao agroforestry system

Values followed by the same letter in each depth (column) are not different according to Scott-Knott test $(P=0.05)$ rubber tree and pasture, with values close to -25 and $-23 \%$, respectively. The secondary forest tended to present more positive results with depth increase. However, the RTP and pasture presented slightly more negative values and approached the forest values starting at $40 \mathrm{~cm}$ depth (Fig. 2). Below $40 \mathrm{~cm}$, there was almost no change in $\delta^{13} \mathrm{C}$ values between systems; while the RTP up to $1 \mathrm{~m}$ depth has values closer to $C_{3}$, the pasture and secondary forest have values closer to the $C_{3}$ and $C_{4}$ mix (Fig. 2). The accumulated $\mathrm{C}-\mathrm{C}_{3}$ at $0-10 \mathrm{~cm}$ depth was $37.95 \mathrm{Mg} \mathrm{ha}^{-1}$ in the secondary forest, $23.90 \mathrm{Mg} \mathrm{ha}^{-1}$ in the pasture and $21.85 \mathrm{Mg} \mathrm{ha}^{-1}$ in the rubber tree plantation. The accumulated $\mathrm{C}-\mathrm{C}_{3}$ from rubber tree was $162 \mathrm{Mg} \mathrm{ha}^{-1}$ up to $100 \mathrm{~cm}$, with very little contribution of $C_{-} C_{4}, 3.4 \mathrm{Mg} \mathrm{ha}^{-1}$. Overall, the $\mathrm{C}_{4}$-origin $\mathrm{C}$ in the pasture was $23.40 \mathrm{Mg} \mathrm{ha}^{-1}$ and $127.36 \mathrm{Mg} \mathrm{ha}^{-1}$ was $\mathrm{C}_{3}$-origin $\mathrm{C}$ along the soil profile (Fig. 3).

\subsection{Aggregate classes and occluded C stock distribution at different depths}

In all land-use systems, there was macroaggregate predominance up to $40 \mathrm{~cm}$ depth. Below this depth, there were a decrease in macroaggregates and an increase in the amount of microaggregates and in the silt + clay fraction. On average, in the first $40 \mathrm{~cm}$, macroaggregates, microaggregates and silt + clay fraction represented 26,19 and $5 \%$ of the soil mass, respectively, while below this depth the aggregate classes accounted for 19,23 and $8 \%$, respectively (Table 4). In general, along the $100 \mathrm{~cm}$ depth, there were variations among the aggregate classes without a defined trend between systems and/or depth (Table 4).

The average amount of $\mathrm{OC}_{\mathrm{Ma}}$ in different land-use systems at $100 \mathrm{~cm}$ depth ranged from 22.50 to $32.15 \mathrm{Mg} \mathrm{ha}^{-1}$, and around $20 \mathrm{Mg} \mathrm{ha}^{-1}$ was found up to $40 \mathrm{~cm}$ depth.

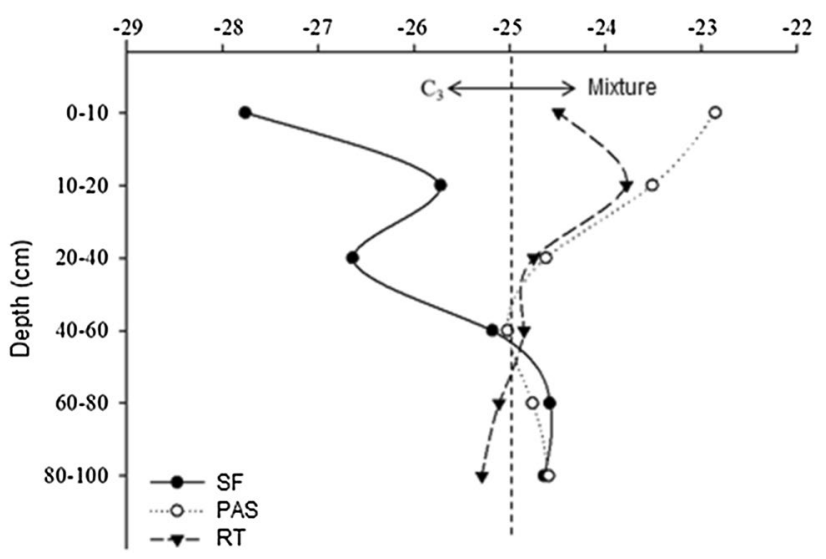

Fig. $2 \delta^{13} \mathrm{C}$ values at different depths of soils under rubber tree agroforestry systems, secondary forest and pasture in Bahia, Brazil. SF: secondary forest; PAS: pasture; RT: rubber tree plantation 

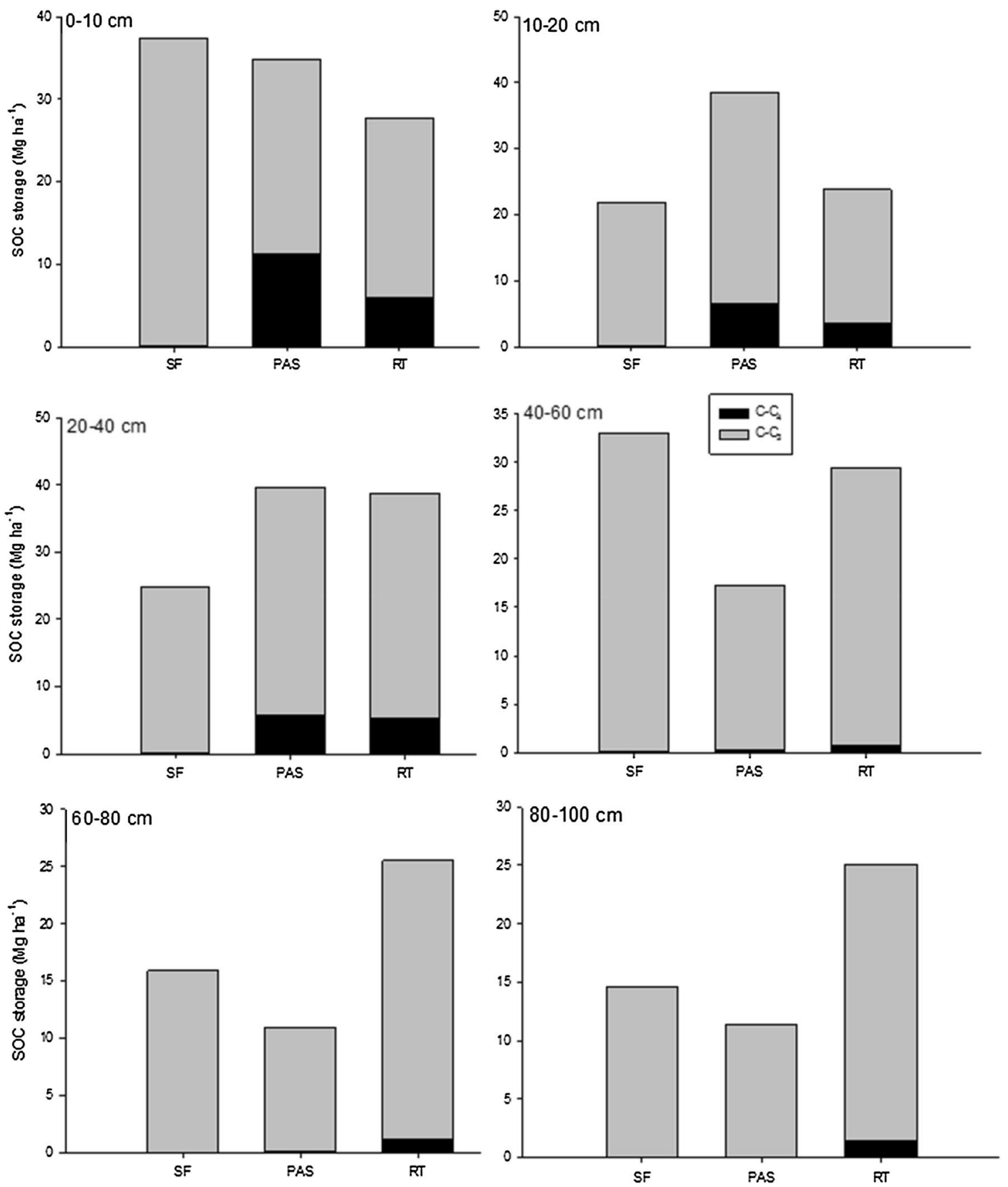

Fig. $3 \mathrm{SOC}$ from $C_{3}$ and $C_{4}$ plants (trees and pasture, respectively) at different depths in rubber tree agroforestry systems, secondary forest and pasture in Bahia. Brazil. SF: secondary forest; PAS: pasture; RT: rubber tree plantation

Microaggregates, on the other hand, showed higher values from this depth, ranging from 12 to $25 \mathrm{Mg} \mathrm{ha}^{-1}$ (Table 3). In the first $40 \mathrm{~cm}$, the amount of $\mathrm{OC}_{\mathrm{Mi}}$ ranged from 5.13 to $9.31 \mathrm{Mg} \mathrm{ha}^{-1}$. Both occluded $\mathrm{C}$ in macroaggregates $\left(\mathrm{OC}_{\mathrm{Ma}}\right)$ and in microaggregates $\left(\mathrm{OC}_{\mathrm{Mi}}\right)$ showed differences between land-use systems (Table 3).

The secondary forest was the system that accumulated the most occluded $\mathrm{C}\left(\mathrm{OC}_{\mathrm{Ma}}+\mathrm{OC}_{\mathrm{Mi}}\right)$ up to $1 \mathrm{~m}$
(58 $\mathrm{Mg} \mathrm{ha}^{-1}$ ), representing 35\% of SOC stock (Fig. 4). The rubber tree + açaí AFS and pasture accumulated around $53 \mathrm{Mg} \mathrm{ha}^{-1}$ and $52 \mathrm{Mg} \mathrm{ha}^{-1}$, representing approximately $41 \%$ and $35 \%$ of the SOC stock, respectively. The rubber tree + cacao AFS presented $50 \mathrm{Mg} \mathrm{ha}^{-1}$ of occluded C, which represented $54 \%$ of SOC stock. The RTP showed the lowest value of occluded $\mathrm{C}$, around $43 \mathrm{Mg} \mathrm{ha}^{-1}$, representing only $24 \%$ of the SOC stock (Fig. 4). 
Table 4 Depthwise distribution of different soil size fractions in rubber tree agroforestry systems, secondary forest and pasture in Bahia, Brazil

\begin{tabular}{|c|c|c|c|c|c|c|}
\hline \multirow[t]{2}{*}{ Depth (cm) } & \multirow[t]{2}{*}{$\begin{array}{l}\text { Particle size } \\
\text { fraction }(\mu \mathrm{m})\end{array}$} & \multirow[t]{2}{*}{ SF } & \multirow{2}{*}{$\begin{array}{l}\text { PAS } \\
\text { Mass of soil }\end{array}$} & \multirow{2}{*}{$\begin{array}{l}\text { RT } \\
\text { Fractions (\%)* }\end{array}$} & \multirow[t]{2}{*}{$\mathrm{RT}+\mathrm{A}$} & \multirow[t]{2}{*}{$\mathrm{RT}+\mathrm{C}$} \\
\hline & & & & & & \\
\hline \multirow[t]{3}{*}{$0-10$} & $>250$ & $60.00^{\mathrm{ns}}$ & 57.35 & 50.72 & 56.59 & 56.26 \\
\hline & $>53$ & $28.75^{\mathrm{ns}}$ & 32.27 & 36.80 & 32.83 & 30.52 \\
\hline & $<53$ & $5.49^{b}$ & $7.31^{b}$ & $10.61^{\mathrm{a}}$ & $8.71^{a}$ & $10.32^{\mathrm{a}}$ \\
\hline \multirow[t]{3}{*}{$10-20$} & $>250$ & $51.22^{\mathrm{ns}}$ & 51.97 & 47.04 & 50.09 & 50.48 \\
\hline & $>53$ & $34.73^{\mathrm{ns}}$ & 37.39 & 38.54 & 38.51 & 35.53 \\
\hline & $<53$ & $8.79^{\text {ns }}$ & 7.89 & 11.72 & 10.98 & 11.41 \\
\hline \multirow[t]{3}{*}{$20-40$} & $>250$ & $51.61^{\mathrm{a}}$ & $40.16^{b}$ & $43.31^{b}$ & $50.28^{\mathrm{a}}$ & $43.66^{b}$ \\
\hline & $>53$ & $33.08^{\mathrm{ns}}$ & 45.02 & 39.94 & 36.72 & 39.66 \\
\hline & $<53$ & $10.39^{\mathrm{ns}}$ & 12.16 & 14.31 & 11.09 & 14.08 \\
\hline \multirow[t]{3}{*}{$40-60$} & $>250$ & $35.73^{\mathrm{ns}}$ & 33.58 & 38.28 & 46.64 & 40.21 \\
\hline & $>53$ & $45.62^{\mathrm{a}}$ & $49.76^{a}$ & $41.76^{\mathrm{b}}$ & $38.44^{b}$ & $41.53^{b}$ \\
\hline & $<53$ & 12.63 & 13.91 & 17.21 & 12.85 & 15.90 \\
\hline \multirow[t]{3}{*}{$60-80$} & $>250$ & $32.59 \mathrm{~b}$ & $31.75^{\mathrm{b}}$ & $32.68^{\mathrm{b}}$ & $41.83^{a}$ & $35.17^{b}$ \\
\hline & $>53$ & $47.09^{a}$ & $50.00^{\mathrm{a}}$ & $44.85^{b}$ & $41.88^{b}$ & $43.42^{b}$ \\
\hline & $<53$ & $15.00^{\mathrm{ns}}$ & 15.70 & 19.19 & 14.31 & 17.49 \\
\hline \multirow[t]{3}{*}{ 80-100 } & $>250$ & $30.77^{\mathrm{ns}}$ & 32.44 & 34.01 & 38.91 & 36.06 \\
\hline & $>53$ & $47.49^{a}$ & $48.56^{\mathrm{a}}$ & $44.34^{\mathrm{b}}$ & $42.53^{b}$ & $42.34^{b}$ \\
\hline & $<53$ & $14.75^{\mathrm{b}}$ & $16.37^{b}$ & $17.98^{\mathrm{a}}$ & $15.66^{\mathrm{b}}$ & $18.94^{\mathrm{a}}$ \\
\hline
\end{tabular}

SF secondary forest, $P A S$ pasture, $R T$ rubber tree plantation, $R T+A$ rubber tree and açai agroforestry system, $R T+C$ rubber tree and cacao agroforestry system

*Values followed by the same letter within size fraction and each depth are not different according to Scott-Knott test $(P=0.05)$

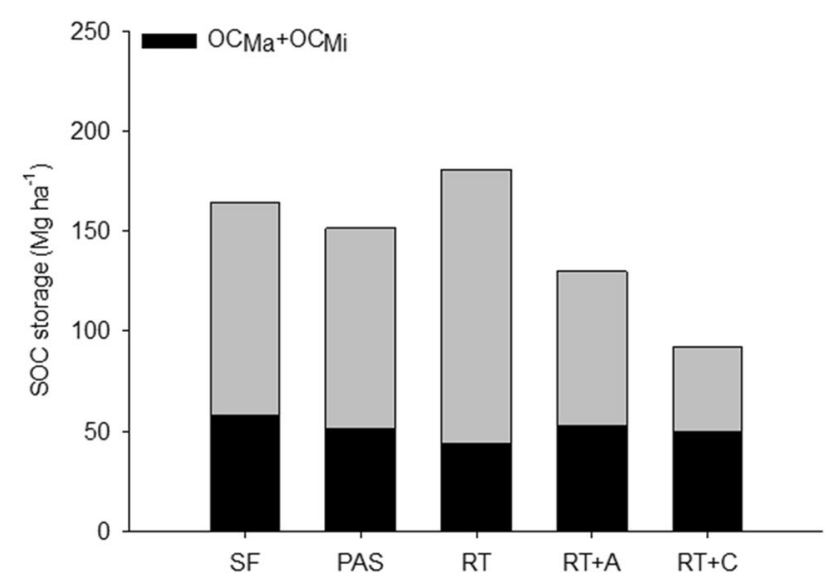

Fig. 4 Contribution of occluded $\mathrm{C}\left(\mathrm{OC}_{\mathrm{Ma}}+\mathrm{OC}_{\mathrm{Mi}}\right)$ in soil organic carbon (SOC), up to $1 \mathrm{~m}$. SF: secondary forest; PAS: pasture; RT: rubber tree plantation; $\mathrm{RT}+\mathrm{A}$ : rubber tree and açai agroforestry system; $\mathrm{RT}+\mathrm{C}$ : rubber tree and cacao agroforestry system. There were no statistical differences of occluded $\mathrm{C}\left(\mathrm{OC}_{\mathrm{Ma}}+\mathrm{OC}_{\mathrm{Mi}}\right)$ among the landuse systems

\section{Discussion}

\subsection{Soil organic carbon (SOC) stock}

The forest to rubber + cacao AFS conversion reduced SOC stock up to $100 \mathrm{~cm}$ approximately $72 \mathrm{Mg} \mathrm{ha}^{-1}$, and the reduction in SOC stock after forest to rubber tree + açaí AFS was around $34 \mathrm{Mg} \mathrm{ha}^{-1}$ (Fig. 1). This low SOC stock in AFSs was not expected, as these polyculture systems are able to accumulate similar or even higher values of SOC when compared to native forest systems or planted forests [45], even in soils with low fertility levels. The SOC stocks found in the present study were lower, mainly in agroforestry systems, than those shown by Monroe et al. [30] and Gama-Rodrigues et al. [17]. These authors found SOC stock up to $100 \mathrm{~cm}$ depth in the older agroforestry systems, similar to that of the secondary forest, and attributed this result as a consequence of a large litter deposition that occurs in these planted systems. Consequently, the following question came up: What factors could explain the reduced SOC stock found here, compared to other areas of AFSs in southern Bahia, Brazil? The $C$ stock in soil is influenced by a number of factors, including plant residues deposition (leaves, branches and barks) that returns to the soil; root systems, soil fertility levels (which influence biomass production aboveground and belowground); 
soil texture; decomposition rate (which is dependent on organic matter quality and on the soil's physical-chemical environment); and soil microbial activity. These factors interrelate, which makes it difficult to establish which one is the most preponderant. In the present study, soils in all systems presented high acidity and low fertility (Table 2) due to interruption of fertilization, which may have led to a reduction in the production of vegetal biomass and, therefore, a low return of vegetal residues to the soil. In addition, this soil chemical status may have negatively affected the activity and microbial diversity and, consequently, the organic matter decomposition, resulting in a reduction in the rates of nutrient and $\mathrm{C}$ transformation, leading to SOC stock reduction $[22,29]$.

The rubber tree plantation, on the other hand, was the most efficient system, storing approximately $17 \mathrm{Mg} \mathrm{ha}^{-1}$ more SOC than the secondary forest up to $100 \mathrm{~cm}$. Of the total stored in the rubber tree plantation, the greater part (around 70\%) was below $20 \mathrm{~cm}$ depth. The other systems, on the other hand, accumulated $70 \%$ of the SOC in the first $40 \mathrm{~cm}$ (Fig. 1 and Table 3). The total SOC stock in the RTP represented a $\mathrm{C}$ accumulation rate around $0.4 \mathrm{MgC} \mathrm{ha}^{-1}$ year $^{-1}$, which is a less significant value, if compared, for example, with the rate of $1.1 \mathrm{MgCha}{ }^{-1}$ year $^{-1}$ in soils up to $60 \mathrm{~cm}$ in depth under rubber tree plantations between 4 and 15 years of age in Brazil [27] and, in China, $0.72 \mathrm{Mg} \mathrm{C}$ ha $^{-1}$ year $^{-1}$ in soils up to $100 \mathrm{~cm}$ under rubber tree plantations with ages varying from 3 to 38 years old [49]. However, our result about the $C$ accumulation rate found in the RTP was similar to that obtained by Wauters et al. [48]. They found a $\mathrm{C}$ accumulation rate in the order of 0.23 to $0.49 \mathrm{Mg}$ $\mathrm{C}$ ha $^{-1}$ year $^{-1}$ in rubber tree roots aged 2 to 26 years. A rubber tree can reach $46.4 \mathrm{Mg} \mathrm{ha}^{-1}$ of root biomass, and its roots account for $15-22 \%$ of $C$ in its biomass [9] because this root system is deep, well developed and can reach $4 \mathrm{~m}$ depth $[27,50]$. Roots have a fundamental role in $C$ sequestration in depth because root cycling and decomposition of dead roots represent a high input of organic matter in soil, and also because of roots' high soil stabilization potential [36, 39]. Vicente et al. [46] also found larger SOC stock in Ultisol under RTP (around $220 \mathrm{Mg} \mathrm{ha}^{-1}$ ). These authors showed that compared to the secondary forest, the RTP increased around $46 \mathrm{MgC} \mathrm{ha}^{-1}$ up to $1 \mathrm{~m}$. The rubber plantation of the present study stored a significant amount of SOC. However, in the first $20 \mathrm{~cm}$, we recorded a decrease of $14 \mathrm{Mg} \mathrm{ha}^{-1}$ and $21 \mathrm{Mg} \mathrm{ha}^{-1}$ in relation to the secondary forest and pasture, respectively (Table 3), probably due to rapid decomposition and low residence time of the rubber tree litter, which reduces substrate production for organic matter formation in soil. Despite $C$ losses that can occur in the conversion of secondary forest to pasture [18], in the present study the SOC stock in the pasture was similar to that in the secondary forest, suggesting that it was able to partially replace the $\mathrm{C}$ lost in surface in this 8-year period. We can attribute these results to a pasture's capacity to develop extensive root systems with high biomass production, as well as to maintain an active rhizosphere due to death and decomposition of root systems which creates a favorable biological condition for $C$ storage [35].

\section{Variation in $\delta^{13} \mathrm{C}$ with depth in secondary forest, pasture and rubber tree plantation}

The principle of the natural ${ }^{13} \mathrm{C}$ abundance method is based on the degree of discrimination between the two stable isotopes of carbon, ${ }^{13} \mathrm{C}$ and ${ }^{12} \mathrm{C}$. The ${ }^{13} \mathrm{C} /{ }^{12} \mathrm{C}$ soil ratio (expressed in $\delta^{13} \mathrm{C}$ ) varies based on the $C$ assimilation pathway of the species that prevails in the system. From the total SOC accumulated up to $100 \mathrm{~cm}$ depth from the pasture, $85 \%$ was $\mathrm{C}_{3}$-origin $C$ probably derived from natural forest that existed before the pasture was established (Fig. 3), as well as from 30 years of grassland vegetation (i.e., Brachiaria decumbens) during fallow. In the RTP, there was also a predominance of $C_{3}$-origin $C$ but we cannot affirm that this is only from rubber trees. The species that use the $C_{3}$ pathway discriminate against ${ }^{13} \mathrm{C}$ uptake more than the species that use the $C_{4}$ pathway. Therefore, the amount of $\delta^{13} \mathrm{C}$ is lower (mean values of $-28 \%$ ofor $C_{3}$ and $-12 \%$ ofor $C_{4}$ ) when $C_{3}$ plants prevail. Thus, the natural ${ }^{13} \mathrm{C}$ abundance method can be used to determine the relative contributions of $C_{3}$ and $C_{4}$ plants-derived $C$ in the total SOC and to estimate the turnover of SOM when the original photosynthetic pathway of organic inputs is changed, independent of the plant species involved in each of these groups $\left(C_{3}\right.$ or $\left.C_{4}\right)([3,6,5,23,28,30,46]$; Paul 2016).

So, the $\mathrm{C}-\mathrm{C}_{3}$ could be both from prior (a secondary forest) and new vegetation. It is important to emphasize that, below $20 \mathrm{~cm}$ depth, the RTP started to accumulate more $\mathrm{C}$ than the secondary forest, with a $\mathrm{C}_{3}$-origin $\mathrm{C}$ predominance, $119.57 \mathrm{Mg} \mathrm{ha}^{-1}$ against $99.51 \mathrm{Mg} \mathrm{ha}^{-1}$ from the secondary forest (Fig. 3). Thus, we can suggest that $20 \mathrm{Mg} \mathrm{ha}^{-1}$ of $C$ represented rubber tree roots' contribution in $C$ input to soil during the 35 years of this system's implantation and can explain partially the difference between the secondary forest in $\mathrm{SOC}$ stock up to $100 \mathrm{~cm}$. A rubber tree has a well-developed root system with a high turnover rate, which is a significant source of soil organic matter [26]. The $\mathrm{C}-\mathrm{C}_{4}$ contribution in the rubber tree plantation, as a result of grasses in their understory, was relevant up to the first $40 \mathrm{~cm}$ depth and represented approximately $9 \%$ of SOC stocked up to $100 \mathrm{~cm}$ depth, and in pasture, this contribution was around $15 \%$. Below this depth, the influence of $\mathrm{C}_{4}$ was very low, not exceeding $2 \%$ of SOC in these two systems (Fig. 3). We can highlight that a period of 8 years after forest into pasture conversion allowed the 
incorporation of $24 \mathrm{Mg} \mathrm{ha}^{-1}$ of $\mathrm{C}_{4}$-derived $\mathrm{C}$ from grasses up to $100 \mathrm{~cm}$ depth which suggests a high carbon turnover time in this land-use system.

\subsection{Aggregate classes' distribution and occluded C stock at different depths}

Since the soils used in this study stored $\mathrm{SOC}$ in the range of 92-181 Mg Cha ${ }^{-1}$ to $100 \mathrm{~cm}$ depth, it is relevant to know how much of this accumulated SOC is actually physically protected and can be considered stabilized $C$ in these soils. The macroaggregates predominance and larger $\mathrm{OC}_{\mathrm{Ma}}$ stock in the first $40 \mathrm{~cm}$ depth (Tables 3,4$)$ suggest that macroaggregation was the main $C$ stabilization mechanism up to this depth. Macroaggregation restriction to surface soil is the result of greater availability of fresh plant residues deposited in the soil by these systems. The surface residue induces the formation of macroaggregates because it is a $\mathrm{C}$ source for microbial activity and the production of microbial-derived binding agents [42]. GamaRodrigues et al. [17], on the other hand, found macroaggregation predominance and higher occluded $C$ stock in this fraction up to $100 \mathrm{~cm}$ depth. The authors attributed these results to the constant addition of organic matter via litterfall and tree roots of both cacao and shade trees. Vicente et al. [46] also observed a macroaggregate predominance and significant occluded $C$ stock in this large fraction (around $50 \mathrm{Mg} \mathrm{ha}^{-1}$ ), which represented almost $30 \%$ of SOC storage up to $1 \mathrm{~m}$ depth. According to Tisdall and Oades [44], the deposited amount of organic matter, more than its quality, is important in soil aggregates formation.

The microaggregates, on the other hand, were predominant and had a higher occluded $C$ stock below $40 \mathrm{~cm}$ (Tables 3,4), probably due to a rise in clay content in deeper horizons, since clay is an important binding agent for soil microaggregates stabilization [20]. In addition, persistent agents involved in microaggregates formation are C from microbial origin [44], i.e., resulting from the continuous microbial cycling of labile material in deep soils [39]. In this case, below $40 \mathrm{~cm}$ depth microaggregates represent stable $C$ and therefore are protected from decomposition in these soils.

Rubber tree + cacao AFS was the system that most contributed with occluded $\mathrm{C}$ in aggregates (almost $60 \%$ ) in relation to the $S O C$ stored up to $100 \mathrm{~cm}$ depth. Next were rubber tree + açaí AFS, pasture, secondary forest and finally the RTP that contributed with $24 \%$ of occluded C in soil aggregates (Fig. 4). The soils under rubber tree + cacao and rubber tree + açaí AFSs were the ones that presented high clay content along soil profile. Clay fraction, iron and aluminum oxides are fundamental for organomineral complex formation (clay-polyvalent metal-organic matter) that form soil aggregates and, consequently, promote physical protection of SOC [44]. Additionally, the occlusion of $C$ in soil aggregates could be attributed to the continuous deposition of plant residues, the presence of decomposing roots, root exudates (which act as a binding agent), root length and also the presence of fungal hyphae [44]. A rubber tree, as previously mentioned, produces litter with a high decomposition rate and reduced turnover time, which does not contribute to secondary compounds' formation in the soil aggregation process [7].

Then, the results of the present study suggest that the RTP favors more labile $\mathrm{C}$ production. On the other hand, during the transformation of organic matter in the rubber tree + cacao and rubber tree + açaí agroforestry systems, there is a preservation of the most recalcitrant compounds of $C$ once cacao and açaí produce high amounts of cellulose-rich and lignin-rich residues [30] that regulate residue decomposition rates and act as substrates for the formation and stabilization of $C$ within the aggregates.

\section{Conclusion}

The RTP system presented the highest SOC values, up to $100 \mathrm{~cm}$ depth, contributing with $20 \mathrm{Mg} \mathrm{Cha}^{-1}$ from belowground input, during 35-year old of system implantation. However, about $90 \%$ of SOC was not physically protected in the soil aggregates. The rubber tree + cacao and rubber tree + açaí AFSs stored the smallest amount of SOC with a significant contribution of stable occluded $C$ in soil aggregates. Macroaggregation and microaggregates were the main mechanisms of $C$ physical protection in the first $40 \mathrm{~cm}$ and below this depth, respectively. These results indicate that AFSs are more efficient in producing stable $C$ in soil which is protected from decomposition, minimizing $\mathrm{CO}_{2}$ emissions into the atmosphere. Thus, the present study supports the role of AFSs as environmental service providers that could supply an additional income through the $\mathrm{C}$ credit sale, which creates a favorable outlook for the small farmers and, therefore, could encourage the agroforestry expansion in Brazil.

Acknowledgements We thank Coordination of Improvement of Higher Level Personnel (CAPES-Brazil) for granting a doctor science scholarship to the first author. This research was partially supported by a grant from Rio de Janeiro Research Foundation (FAPERJ) (E-26/110.745/2013) and Brazilian National Council for Scientific and Technological Development (CNPq) (475740/2010-6). We thank CEPLAC for the technical support during the soil sampling. We are grateful to Kátia R. Nascimento Sales, Ederaldo Azeredo Silva and Vanilda Ribeiro de Souza of Soil Laboratory, North Fluminense State University for the technical support in soil sample collection and analysis. The authors thank the anonymous reviewers for their comments and suggestions on the manuscript. 


\section{Compliance with ethical standards}

Conflict of interest On behalf of all authors, the corresponding author states that there is no conflict of interest.

\section{References}

1. Alvim R, Virgens AC, Araújo AC (1989) Agroforestry as a science of earning money on land of early recovery and capital compensation in the establishment of perennial tree crops. CEPLAC/ CEPEC, Bahia, Brazil, Boletim Técnico, vol 161

2. Balesdent J, Balabane M (1996) Major contribution of roots to soil carbon storage inferred from maize cultivated soils. Soil Biol Biochem 28:1261-1263. https://doi.org/10.1016/00380717(96)00112-5

3. Balesdent J, Mariotti A, Guillet B (1987) Natural ${ }^{13} \mathrm{C}$ abundance as a tracer for studies of soil organic matter dynamics. Soil Biol Biochem 19:25-30

4. Bernoux M, Cerri CC, Neill C, Moraes JFL (1998) The use of stable carbono isotopes for estimating soil organic matter turnover rates. Geoderma 82:43-50. https://doi.org/10.1016/S0016 -7061(97)00096-7

5. Bird MI (1997) Variations of $\delta 13 C$ in the surface soil organic carbon pool. Global Biogeoche Cycles 11:313-322

6. Boutton TW, Archer SR, Midwood AJ, Zitzer SF, Bol R (1998) $\delta 13 C$ values of soil organic carbon and their use in documenting vegetation change in a subtropical savanna ecosystem. Geoderma 82:5-41

7. Bronick CJ, Lal R (2005) Soil structure management: a review. Geoderma 124:3-22. https://doi.org/10.1016/j.geode rma.2004.03.005

8. Chepote RE, Santana SO, Araujo QR, Sodré GA, Reis EL, Pacheco RG, Marrocos PC (2012) Agricultural potential and soil fertility for cacao crop. In: Valle RR (ed) Science, technology and management of cacao tree. CEPLAC/CEPEC, Brasília, pp 67-114

9. Cunha TJF, Blancaneaux $P$, Calderano Filho B (2000) Influência da diferenciação pedológica no desenvolvimento da seringueira no município de Oratórios, MG. Pesquisa Agropecuaria Brasileira 35:145-155

10. Dawoe EK, Issac ME, Quashie-Sam J (2010) Litterfall and litter nutrient dynamics under cocoa ecosystems in lowland humid Ghana. Plant Soil 330:55-64. https://doi.org/10.1007/s1110 4-009-0173-0

11. Dixon RK (1995) Agroforestry systems: sources or sinks of greenhouse gases? Agrofor Syst 31:99-116. https://doi.org/10.1007/ bf00711719

12. Elliot ET (1986) Aggregate structure and carbon, nitrogen and phosphorus in native and cultivated soils. Soil Sci Soc Am J 50:627-633

13. Ellert BH, Bettany JR (1995) Calculation of organic matter and nutrients stored in soils under contrasting management regimes. Can J Soil Sci 75:529-538. https://doi.org/10.4141/cjss9 5-075

14. EMBRAPA. Embrapa Solos (2017) Manual de métodos de análise de solos, 3rd ed, p 573. Brasília, DF

15. Farquhar GD, Ehleringer IJR, Hubick KT (1989) Carbon isotope discrimination and photosynthesis. Annu Rev Plant Physiol Plant Mol Biol 40:503-537

16. Fontes AG, Gama-Rodrigues AC, Gama-Rodrigues EF, Sales MVS, Costa MG, Machado RCR (2014) Nutrient stocks in litterfall and litter in cocoa agroforests in Brazil. Plant Soil 383:313-335. https ://doi.org/10.1007/s11104-014-2175-9
17. Gama-Rodrigues EF, Nair PKR, Nair VD, Gama-Rodrigues AC, Baligar VC, Machado RCR (2010) Carbon storage in soil size fractions under two cacao agroforestry systems in Bahia, Brazil. Environ Manag 45:274-283. https://doi.org/10.1007/s0026 7-009-9420-7

18. Guo LB, Gifford RM (2002) Soil carbon stocks and land use change: a meta analysis. Glob Change Biol 8:345-360. https:// doi.org/10.1046/j.1354-1013.2002.00486.x

19. Jobbagy EG, Jackson RB (2000) The vertical distribution of soil organic carbon and its relation to climate and vegetation. Ecol Appl 10:423-436. https://doi.org/10.2307/2641104

20. Kölbl A, Kögel-Knabner I (2004) Content and composition of free and occluded particulate organic matter in a differently textured arable cambisol as revealed by solid-state ${ }^{13} \mathrm{C}$ NMR spectroscopy. J Plant Nutr Soil Sci 167:45-53. https://doi.org/10.1002/ jpln.200321185

21. Kumagai T, Mudd RG, Giambelluca TW, Kobayashi N, Miyazawa Y, Lim TK, LiuW Huang M, Fox JM, Ziegler AD, Yin S, Mak SV, Kasemsap P (2015) How do rubber (Hevea brasiliensis) plantations behave under seasonal water stress in northeastern Thailand and central Cambodia? Agric For Meteorol 213:10-22. https:// doi.org/10.1016/j.agrformet.2015.06.011

22. Kunito T, Isomura I, Sumi H, Park HD, Toda H, Otsuka S, Nagaoka K, Saeki K, Senoo K (2016) Aluminum and acidity suppress microbial activity and biomass in acidic forest soils. Soil Biol Biochem 97:23-30. https://doi.org/10.1016/j.soilbio.2016.02.019

23. Lefroy RDB, Blair GJ, Strong WM (1993) Changes in soil organic matter with cropping as measured by organic carbon fractions and ${ }^{13} \mathrm{C}$ natural isotope abundance. Plant Soil 155/156:399-402

24. Lima AMN, Silva IR, Neves JCL, Novais RF, Barros NF, Mendonça ES, Smyth TJ, Moreira MS, Leite FP (2006) Soil organic carbon dynamics following afforestation of degraded pastures with eucalyptus in Southeastern Brazil. For Ecol Manag 235:219-231. https://doi.org/10.1016/j.foreco.2006.08.331

25. Lugo AE, Cuevas E, Sanchez MJ (1990) Nutrients and mass in litter and soil of ten tropical tree plantations. Plant Soil 125:263-280

26. Maeght J-L, Gonkhamdee S, Clément C, Ayutthaya SIN, Stokes A, Pierret A (2015) Seasonal patterns of fine root production and turnover in a mature rubber tree (Hevea brasiliensis müll. arg.) stand- differentiation with soil depth and implications for soil carbon stocks. Front Plant Sci 6:1-11. https://doi.org/10.3389/ fpls.2015.01022

27. Maggiotto SR, Oliveira D, Marur CJ, Stivari SMS, Leclerc M, Wagner-Riddley C (2014) Potential carbon sequestration in rubber tree plantations in the northwestern region of the Paraná State, Brazil. Acta Sci Agron 36:239-245. https://doi.org/10.4025/actas ciagron.v36i2.17404

28. Martin A, Mariotti A, Balesdent J, Lavelle P, Vuattoux R (1990) Estimate of organic matter turnover rate in a savanna soil by 13C natural abundance measurements. Soil Biol Biochem 22:517-523

29. Mbuthia LW, Acosta-Martínez V, DeBruyn J, Schaeffer S, Tyler D, Odoi E, Mpheshea M, Walker F (2015) Long term tillage, cover crop, and fertilization effects on microbial community structure, activity: implications for soil quality. Soil Biol Biochem 89:24-34. https://doi.org/10.1016/j.soilbio.2015.06.016

30. Monroe PHM, Gama-Rodrigues EF, Gama-Rodrigues AC, Marques JRB (2016) Soil carbon stocks and origin under different cacao agroforestry systems in Southern Bahia, Brazil. Agric Ecosyst Environ 221:99-108. https://doi.org/10.1016/j. agee.2016.01.022

31. Moraes JFL, Volkoff B, Cerri CC, Bernoux M (1996) Soil properties under Amazon forest and changes due to pasture installation in Rondônia, Brazil. Geoderma 70:63-81. https://doi. org/10.1016/0016-7061(95)00072-0 
32. Müller MW, Gama-Rodrigues AC (2012) Cacao agroforestry systems. In: Valle RR (ed) Science, technology and management of cacao tree. CEPLAC/CEPEC, Brasília, pp 246-271

33. Nair PKR, Gordon, AM, Mosquera-Losada MR (2008) Agroforestry. In: Jorgensen SE, Fath BD (eds.), Ecological engineering, 1, of encyclopedia of ecology, vol 5, pp 101-110. Elsevier, Oxford

34. Nair PKR, Kumar BM, Nair VD (2009) Agroforestry as a strategy for carbon sequestration. J Plant Nutr Soil Sci 172:10-23. https ://doi.org/10.1002/jpln.200800030

35. Ojeda JJ, Caviglia OP, Agnusdei MG (2018) Vertical distribution of root biomass and soil carbon stocks in forage cropping systems. Plant Soil 423:175-191. https://doi.org/10.1007/s1110 4-017-3502-8

36. Rasse DP, Rumpel C, Dignac M-F (2005) Is soil carbon mostly root carbon? mechanisms for a specific stabilization. Plant Soil 269:341-356. https://doi.org/10.1007/s11104-004-0907-y

37. Rita JCO, Gama-Rodrigues EF, Gama-Rodrigues AC, Polidoro JAC, Machado RC (2011) C e N contents in density fraction of whole soil and soil size fraction under cacao agroforest system and natural forests in Bahia, Brazil. Environ Manag 48:134-141. https ://doi.org/10.1007/s00267-011-9642-3

38. Roscoe R, Buurman P, Velthorst EJ (2000) Disruption of soil aggregates by varied amounts of ultrasonic energy in fractionation of organic matter of a clay latosol: carbon, nitrogen and $13 \mathrm{C}$ distribution in particle-size fractions. Eur J Soil Sci 51:445-454. https://doi.org/10.1046/j.1365-2389.2000.00321.x

39. Rumpel C, Kögel-Knabner I (2011) Deep soil organic matter-a key but poorly understood component of terrestrial C cycle. Plant Soil 338:143-158. https://doi.org/10.1007/s1110 4-010-0391-5

40. Sá MAC, Lima JM (2005) Energia ultra-sônica: uma ferramenta em ciência do solo. Empresa Brasileira de Pesquisa Agropecuária. Embrapa Cerrados, Planaltina, DF, Documentos 139

41. Schroth G, Lehmann J, Rodrigues MRL, Barros E, Macêdo JLV (2001) Plant-soil interactions in multistrata agroforestry in the humid tropics. Agrofor Syst 53:85-102. https://doi. org/10.1023/A:1013360000633

42. Six J, Paustian K (2014) Aggregate-associated soil organic matter as an ecosystem property and a measurement tool.
Soil Biol Biochem 68:A4-A9. https://doi.org/10.1016/j.soilb io.2013.06.014

43. Systat Software Inc (2010) Sigmaplot for windows (development and testing 526 procedure) Version 11.0

44. Tisdall JM, Oades JM (1982) Organic matter and water-stable aggregates in soils. J Soil Sci 33:141-163. https://doi. org/10.1111/j.1365-2389.1982.tb01755.x

45. Tumwebaze SB, Byakagaba $P$ (2016) Soil organic carbon stocks under coffee agroforestry systems and coffee monoculture in Uganda. Agric Ecosyst Environ 216:188-193. https://doi. org/10.1016/j.agee.2015.09.037

46. Vicente LC, Gama-Rodrigues EF, Gama-Rodrigues AC (2016) Soil carbon stocks of Ultisols under different land use in the Atlantic rainforest zone of Brazil. Geoderma Region 7:330-337. https:// doi.org/10.1016/j.geodrs.2016.06.003

47. Vitorello VA, Cerri CC, Andreux F, Victória RL (1989) Organic matter and natural carbon-13 distributions in forested and cultivated oxisols. Soil Sci Soc Am J 53:773-778. https://doi. org/10.2136/sssaj1989.03615995005300030024x

48. Wauters JB, Coudert S, Grallien E, Jonard M, Ponette Q (2008) Carbon stock in rubber tree plantations in Western Ghana and Mato Grosso (Brazil). Forest Ecol Manag 255:2347-2361. https ://doi.org/10.1016/j.foreco.2007.12.038

49. Yang JG, Huang JH, Tang JW, Pan QM, Han XG (2005) Carbon sequestration in rubber tree plantations established on former arable lands in Xishuangbanna, SW China. Acta Phytoecol Sinica 29:296-303

50. Yang X, Blagodatsky S, Liu F, Beckschäfer P, Xu J, Cadisch G (2017) Rubber tree allometry, biomass partitioning and carbon stocks in mountainous landscapes of sub-tropical China. For Ecol Manage 15:84-99. https://doi.org/10.1016/j.foreco.2017.08.013

Publisher's Note Springer Nature remains neutral with regard to jurisdictional claims in published maps and institutional affiliations. 